\title{
Epithelial trophoblastic tumor associated with in situ squamous cell carcinoma of the cervix
}

Primeira submissão em 26/10/09 Última submissão em 27/10/09 Aceito para publicação em $07 / 02 / 10$ Publicado em 20/04/10

\section{Tumor trofoblástico epitelioide associado a carcinoma epidermoide in situ cervical}

Eduardo Cambruzzi'; Karla Lais Pêgas²; Dennis Baroni Cruz³; Pedro Guilherme Schaefer ${ }^{4}$

\section{key words}

Gynecological neoplasias

Squamous cell carcinoma

Pathology

Immunohistochemistry

\section{abstract}

Epithelioid trophoblastic tumors are rare neoplasias that develop from the neoplastic transformation of chorionic-type intermediate trophoblasts. They show a wide spectrum of differential diagnoses. The authors describe a case of epithelioid trophoblastic tumor with atypical presentation in a 26-year-old patient that had recently undergone conization for in situ squamous cell carcinoma of the uterine cervix. The histopathology, immunohistochemistry and differential diagnoses of the lesion are also discussed. No similar case had been reported in the medical literature and it is an example of the hindrances to the diagnosis of epithelioid trophoblastic tumors.

\section{resumo}

Os tumores trofoblásticos epitelioides são neoplasias raras que se desenvolvem a partir da transformação neoplásica de trofoblastos intermediários coriônicos, apresentando grande espectro de diagnósticos diferenciais. Os autores descrevem um caso de tumor trofoblástico epitelioide com apresentação atípica em paciente de 26 anos de idade, que apresentava história recente de conização por carcinoma epidermoide in situ do colo uterino. Histopatologia, imuno-histoquímica e diagnósticos diferenciais da lesão também são discutidos. Nenhum caso similar foi descrito na literatura, sendo um exemplo das dificuldades encontradas para diagnosticar os tumores trofoblásticos epitelioides.

\section{unitermos}

Neoplasias ginecológicas

Carcinoma epidermoide

Patologia

Imuno-histoquímica

1. Doutor em Patologia pela Universidade Federal de Ciências da Saúde de Porto Alegre (UFCSPA); professor e chefe da Disciplina de Patologia da Universidade Luterana do Brasil (ULBRA); médico anatomopatologista do Hospital Nossa Senhora da Conceição-RS.

2. Mestranda em Patologia pela UFCSPA; médica anatomopatologista do Hospital das Clínicas de Porto Alegre (HCPA-RS) e da Irmandade Santa Casa de Misericórdia de Porto Alegre-RS.

3. Doutorando em Pneumologia pela Universidade Federal do Rio Grande do Sul (UFRCS); professor de Patologia da Universidade de Santa Cruz do Sul (UNISC); médico anatomopatologista.

4. Mestrando em Patologia pela UFCSPA; médico anatomopatologista. 


\section{Introduction}

Epithelioid trophoblastic tumor (ETT) is a rare neoplasm that represents the most recent addition to the gestational trophoblastic tumor category ${ }^{(1)}$. ETT was originally termed atypical choriocarcinoma when it was first described in the lungs of patients with prior choriocarcinoma following intensive chemotherapy ${ }^{(6,9)}$. The term epithelioid trophoblastic tumor was proposed in $1994^{(10)}$ and, in 1998, Shih and Kurman ${ }^{(13)}$ reported 14 cases of ETT with no history of chemotherapy, suggesting that this neoplasm is a distinct unique pathologic entity and not simply a treatment-related finding ${ }^{(3,4)}$.

The tumor is composed of a monomorphic population of intermediate trophoblastic cells resembling those of membranous chorion. ETT has characteristics and growth pattern which mimic a carcinoma ${ }^{(8,12,14)}$. The following case describes a patient with ETT associated with cervical in situ squamous cell carcinoma that was initially misinterpreted as infiltrative cervical cancer.

\section{Case report}

A 26-year-old woman was sent to the Gynecological Surgery Center due to an alteration on the cervical pathological exam (in situ squamous cell carcinoma of the cervix). She reported three prior pregnancies, her last one in 2004 when urinary tract infection episode required in-patient care. The patient underwent uterine conization and the pathology examination revealed in situ squamous cell carcinoma extending to the endocervical surgical margin. The patient wished to undergo a full hysterectomy, procedure then adopted with the oncology team. The pathology diagnosis was invasive squamous cell carcinoma with necrosis occupying the isthmus and extending into the myometrium.

In gross examination of the hysterectomy specimen showed small tumor occupying the isthmus and anterior uterine body. This tumor measured $0.6 \times 0.6 \times 0.4 \mathrm{~cm}$ and was solid with a tan to brown, friable cut surface. The tumor invaded the superficial myometrium and did not reach the endocervix.

The histological examination revealed atypical cells with relatively abundant strongly eosinophilic cytoplasm and pleomorphic nuclei, lying in sheets and nests (Figure 1), set against a background of extensive geographic necrosis. The tumor cells had polygonal nuclei and visible nucleoli. Blood vessels within the tumor were preserved with occasional deposition of amorphous fibrinoid material on the wall. There were areas where the tumor cells were surrounded by dense eosinophilic, hyaline-like matrix resembling keratin. Also of note was a relatively moderate mitotic count when compared with the degree of cytological atypia. There were some regions of the tumor with 1-2 mitotic cells per 10 high-power fields but mitoses were scant in most other areas. The tumor was well-circumscribed, extended into superficial inner half of the myometrium.

Immunohistochemical staining showed positivity for cytokeratin AE1/3 (Figure 2), CAM5.2 (Figure 3), high-molecular weight cytokeratin and PLAP (Figure 4), while stainings for HCG were negative (Figure 5). The Ki-67 labeling index was approximately 5\% and p63 was focally positive. The findings were diagnostic of epithelioid trophoblastic tumor.

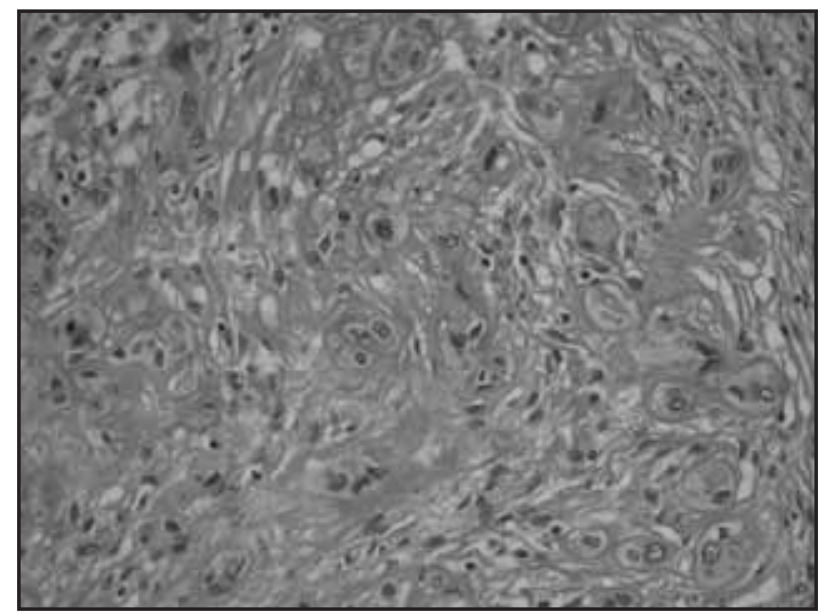

Figure 1 - Epithelioid trophoblastic tumor: epithelioid mononucleate cells with eosinophilic cytoplasm and pleomorphic nuclei, lying in nests

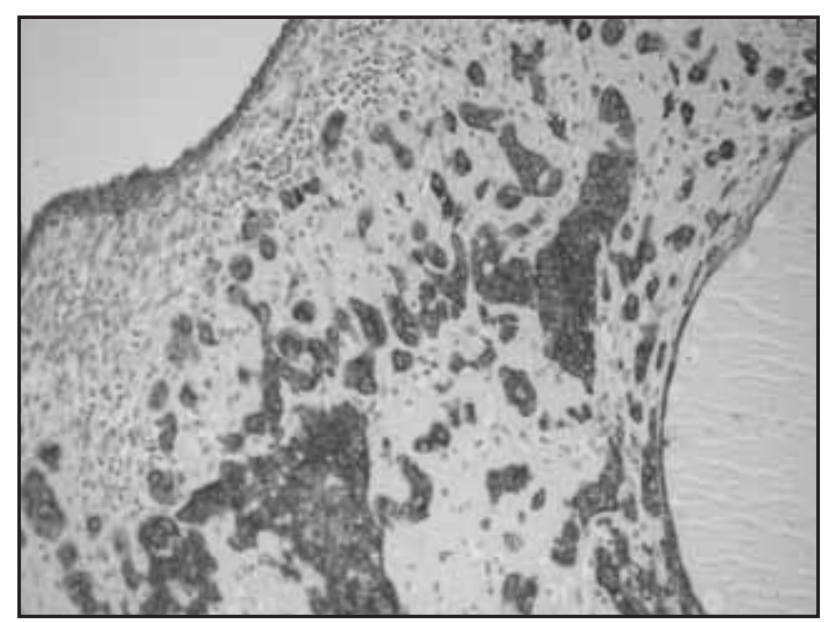

Figure 2 - Epithelioid trophoblastic tumor: immunohistochemical staining showed positivity for cytokeratin $A E 1 / 3$ 


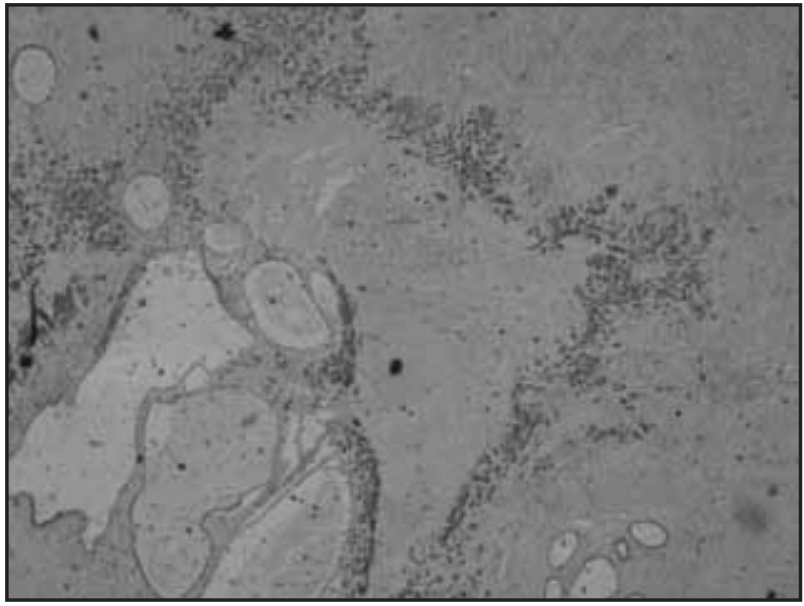

Figure 3 - Epithelioid trophoblastic tumor: immunohistochemical staining showed positivity for CAM 5.2

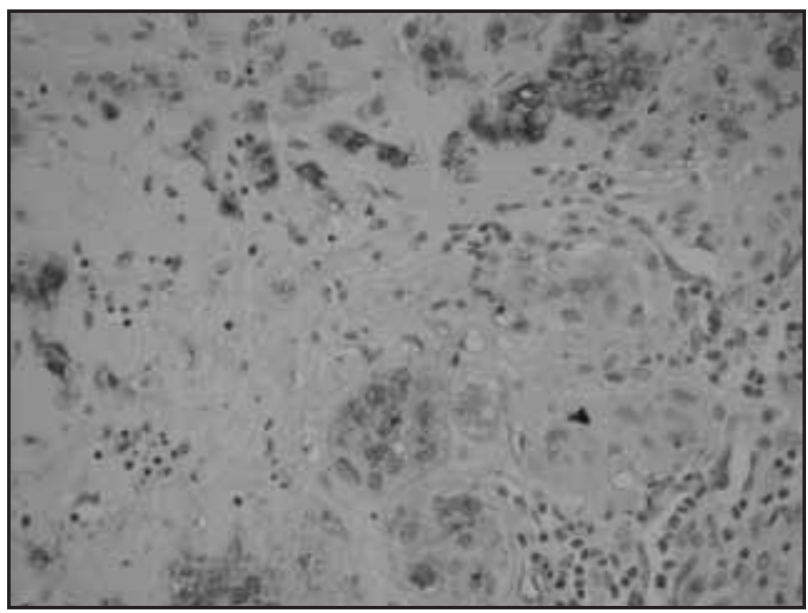

Figure 4 - Epithelioid trophoblastic tumor: immunohistochemical staining showed positivity for PLAP

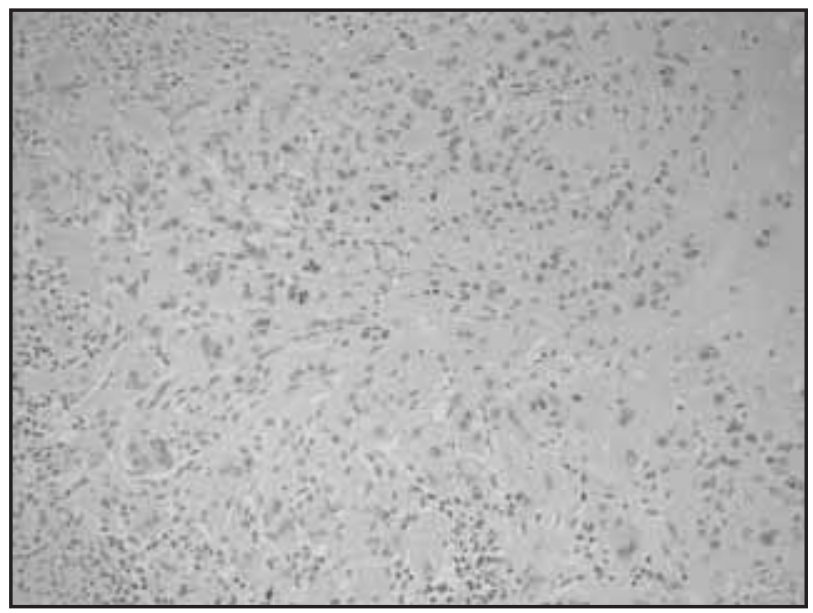

Figure 5 - Epithelioid trophoblastic tumor: immunohistochemical staining showed negativity for HCG

\section{Discussion}

ETTs are rare tumors that develop from neoplastic transformation of chorionic-type intermediate trophoblast ${ }^{(8,10,12,14)}$. Approximately 90 cases have been reported in the literature, including tumors termed atypical choriocarcinoma and nodules of intermediate trophoblast. Patients with this neoplasm are usually in the reproductive age group, with only two reported cases after menopause ${ }^{(6)}$. The patients ranged from 15 to 66 years of age $(6,7,10,11)$.

The reported interval between the previous gestation and diagnosis ranged from 1 to 25 years. Regarding our patient, ETT followed term delivery 1.5 years earlier. Abnormal vaginal bleeding is the most common form of presentation. The most important differential diagnosis is invasive squamous cell carcinoma, particularly, as in our patient, when it spreads to the lower uterine segment ${ }^{(3)}$.

Clinically, ETT may also behave in the same manner as placental site trophoblastic tumor (PSTT) and it is important to distinguish ETT and PSTT from choriocarcinoma because the recommended treatment differs. In contrast to PSTT, the cells of ETT are smaller, display less nuclear pleomorphism and grow in a nodular fashion, while choriocarcinoma is characterized by a dimorphic population of trophoblast ${ }^{(3,4,6,10)}$.

Our case report illustrates the difficulties of diagnosing this rare tumor. The pathological features of $\mathrm{ETT}$, like nodular proliferation of monomorphic epithelioid trophoblast with eosinophilic cytoplasm and areas of hyalinization resembling keratinous material, and the history of cervical cancer in this patient led to an erroneous diagnosis of squamous cell carcinoma.

Clues to the differential diagnosis between ETT and squamous cell carcinoma include clinical and pathological parameters. ETT usually occurs in young patients with vaginal bleeding and recent pregnancy, serum HCG is elevated, although at low levels, and cervical intraepithelial neoplasia is not usually associated. In ETTs exist a nodular proliferation with hyalinization changes and decidualized stromal polygonal cells; the nuclei are convoluted and the cytoplasm is abundant clear to eosinophilic, without of true keratin formation or squamous differentiation (including cell bridges) ${ }^{(2-5,13)}$.

Immunohistochemical stainings are usually positive for inibin, HLA-6, CK18, hPL and HCG ${ }^{(5)}$. The immunohistochemical profile of our case correlates well with the reports in the literature. The focal nuclear positivity 
for p63 stain further supports the diagnosis of ETT. The pathologists should be aware of the fact that this neoplasia is usually positive for cytokeratin and that the positivity for HCG could be focal, making it difficult to make the differential diagnosis from carcinoma ${ }^{(4,8,13)}$.

The prognosis of ETT is similar to that of placental site trophoblastic tumor. Metastasis and death occur in 25 and $10 \%$ of patients, respectively ${ }^{(1-4,13)}$. Our patient is currently well with no clinical evidence of tumor at the last follow-up 2 years after hysterectomy.

\section{Conclusion}

The epithelioid trophoblastic tumor is a recently described neoplasm that may be confused with squamous cell carcinoma and placental site trophoblastic tumor. We report an ETT with atypical presentation, in which the patient had a recent history of conization for cervical in situ squamous cell carcinoma. No similar case had been reported in literature and it is an example of the difficulties in the diagnosing of ETT.

\section{References}

1. CHEUNG, A. N. Pathology of gestational trophoblastic diseases. Best Practice \& Research Clinical Obstetrics and Gynaecology, v. 17, p. 849-68, 2003.

2. COULSON, L. E.; KONG, C. S.; ZALOUDEK, C. Epithelioid trophoblastic tumor of the uterus in a postmenopausal woman: a case report and review of the literature. Am J Surg Pathol, v. 24, p. 1558-62, 2004.

3. FADARE, O. et al. Epithelioid trophoblastic tumor: clinicopathological features with an emphasis on uterine cervical involvement. Modern Pathology, v. 19, p. 75-82, 2006.

4. GENEST, D. R.; BERKOWITZ, R. S.; FISHER, R. A. Gestational trophoblastic disease. In: TAVASSOLI, F. A.; DEVILLE, P. (ed.). Pathology and genetics of tumours of the breast and female genital organs. WHO Classification of Tumours. Lyon: IARC Press, 2003. p. 250-4.

5. HAMAZAKI, S.; NAKAMOTO, S.; OKINO, T. Epithelioid trophoblastic tumor: morphological and immunohistochemical study of three lung lesions. Hum Pathol, v. 30, p. 1321-7, 1999.

6. JONES, W. et al. Thoracotomy in the management of gestational choriocarcinoma: a clinicopathologic study. Cancer, v. 72, p. 2175-81, 1993.

7. KUO, K. T; CHEN, M. J.; LIN, M. C. Epithelioid trophoblastic tumor of the broad ligament: a case report and review of the literature. Am J Surg Pathol, v. 28, p. 405-9, 2004.

8. LO, C. et al. Epithelioid trophoblastic tumor: a case report. Int J Gynecol Cancer, v. 16, p. 1473-6, 2006.

9. MAZUR, M. T. Metastatic gestational choriocarcinoma. Unusual pathologic variant following therapy. Cancer, v. 63, p. 1370-7, 1989.

10. MAZUR, M. T.; KURMAN, R. J. Gestational trophoblastic disease and related lesions. In: KURMAN, R. J. (ed.). Blausteins pathology of the female genital tract. New York: Springer-Verlag, 1994. p. 1049-93.

11. MEYDANLI, M. M.; KUCUKALI, T.; USUBUTUN, A. Epithelioid trophoblastic tumor of the endocervix: a case report. Gynecol Oncol, v. 87, p. 210-24, 2002.

12. NARITA, F. et al. Epithelioid trophoblastic tumor (ETT) initially interpreted as cervical cancer. Int J Gynecol Cancer, v. 13, p. 551-4, 2003.

13. SHIH, I. M. D.; KURMAN, R. J. Epithelioid trophoblastic tumor: a neoplasm distinct from choriocarcinoma and placental site trophoblastic tumor simulating carcinoma. Am J Surg Pathol, v. 22, p. 1393-403, 1998.

14. VENCKEN, P. M. L. H.; EWING, P. C.; ZWEEMER, R. P. Epithelioid trophoblastic tumour: a case report and review of the literature. J Clin Pathol, v. 59, p. 1307-8, 2006. 